Bioeduca: Journal of Biology Education
http://journal.walisongo.ac.id/index.php/bioeduca
ISSN 2714-8009 (print), 2715-7490 (online)
Volume 3, Nomor 1, Tahun 2021
Hal. 46-59

\title{
Hubungan Multiple Intelligences dengan Keterampilan Proses Sains Siswa dalam Pendidikan Biologi Abad 21
}

\author{
Firyal Aulia Ikbari ${ }^{1}$, Rita Istiana ${ }^{2^{*}}$, Triasianingrum ${ }^{3}$, IImi Zajuli Ichsan ${ }^{4}$, \\ Giry Marhento ${ }^{5}$, Ahmad Ali ${ }^{6}$, Wiwin Pramita Arif ${ }^{7}$, Titin $^{8}$ \\ 1,2,3Pendidikan Biologi, Universitas Pakuan \\ ${ }^{4}$ Pendidikan Kependudukan dan Lingkungan Hidup, Universitas Negeri Jakarta \\ ${ }^{5}$ Pendidikan Biologi, Universitas Indraprasta PGRI \\ ${ }^{6,7}$ Pendidikan Biologi, Universitas Islam Negeri Alauddin Makassar \\ ${ }^{8}$ Pendidikan Biologi, Universitas Tanjungpura \\ *Email: rita_istiana@unpak.ac.id
}

\begin{tabular}{|c|c|}
\hline Informasi Artikel & ABSTRAK \\
\hline Submit: $19-10-2020$ & Penelitian ini bertujuan untuk mengetahui hubungan antara \\
\hline Diterima: $29-03-2021$ & Multiple Intelligences dengan keterampilan proses sains, serta \\
\hline Dipublikasikan: $31-03-2021$ & untuk mengetahui kekuatan hubungan, bentuk hubungan dan \\
\hline & hubungan fungsionalnya. Penelitian ini dilaksanakan pada bulan \\
\hline & $\begin{array}{l}\text { Desember } 2019 \text { hıngga Agustus } 2020 \text {. Populası pada penelitian } \\
\text { ini adalah seluruh siswa kelas XI MIPA SMA Negeri } 4 \text { Cibinona }\end{array}$ \\
\hline & tahun ajaran $2019 / 2020$ dengan jumlah sampel sebanyak 154 \\
\hline & responden. Hasil analisis terdapat hubungan positif antara \\
\hline & $\begin{array}{l}\text { Multiple Intelligences dengan keterampilan proses sains, dengan } \\
\text { persamaan regresi } \hat{Y}=27,228+0,128 x \text {. Koefisien korelasi }(r)\end{array}$ \\
\hline & sebesar 0,409 sedangkan koefisien determinasi (r2) dihitung \\
\hline & sebesar $16,7 \%$.. keterampilan proses sains dapat dilihat dari \\
\hline & Multiple Intelligences sedangkan 83,3\% terbentuk dari faktor- \\
\hline & $\begin{array}{l}\text { taktor lain yang turut membentuk keterampllan proses sains } \\
\text { siswa. }\end{array}$ \\
\hline & $\begin{array}{l}\text { Kata kunci: multiple intelligences; keterampilan proses sains; } \\
\text { siswa. }\end{array}$ \\
\hline Penerbit & ABSTRACT \\
\hline Program Studi Pendidikan & This study aims to determine the relationship between Multiple \\
\hline Biologi, Fakultas Sains dan & Intelligences and science process skills, as well as to determine \\
\hline Teknologi, UIN Walisongo & the strength of relationships, the form of relationships and their \\
\hline Semarang & functional relationships. This research was conducted from \\
\hline & December 2019 to August 2020. The population in this study \\
\hline & $\begin{array}{l}\text { were all students of Class XI MIIPA SIMA INegerl } 4 \text { CibInong In the } \\
\text { academic year } 2019 / 2020 \text { with a total sample of } 154 \text { respondents. }\end{array}$ \\
\hline & Results of the analysis show a positive relationship between \\
\hline & Multiple Intelligences and science process skills, with the \\
\hline & regression equation $Y=27.228+0.128 x$. The correlation \\
\hline & calculated at $16.7 \%$. Science process skills can be seen from \\
\hline & $\begin{array}{l}\text { Multiple Intelligences while } 83.3 \% \text { is formed from other factors } \\
\text { that help shape students' science process skills. }\end{array}$ \\
\hline & $\begin{array}{l}\text { Keywords: multiple intelligences; science process skills; } \\
\text { students. }\end{array}$ \\
\hline
\end{tabular}

Copyright @2021, Bioeduca: Journal of Biology Education

Firyal Aulia lkbari et al. - Hubungan Multiple Intelligences Dengan Keterampilan Proses Sains Siswa dalam Pendidikan Biologi Abad 21 


\section{PENDAHULUAN}

Pendidikan merupakan sektor penting didalam kehidupan setiap manusia serta didalam pembangunan disetiap negara. Pendidikan merupakan kebutuhan pokok bagi setiap manusia, karena dengan adanya pendidikan manusia dapat terus belajar dan memahami berbagai macam masalah serta akan dapat mencapai tujuan serta kesejahteraan hidupnya, sehingga manusia dapat mengembangkan potensi dirinya agar dapat mengatasi permasalahan dan memenuhi kebutuhan hidupnya (Camacho \& Legare, 2015; Cukurova \& Bennett, 2018; Saputri et al., 2019; Sharif \& Cho, 2015). Akan tetapi selama ini orang yang diyakini memiliki potensi lebih diidentikkan pada IQ, siswa yang memiliki IQ tinggi dianggap siswa yang paling baik, sehingga mereka diperkenankan mengambil pelajaran yang menuntut keterampilan bacaan, perhitungan, dan pemikiran penting. Siswa memiliki IQ tinggi dianggap paling cerdas dan dapat masuk ke perguruan tinggi yang lebih baik. Belum bisa dikatakan cerdas seseorang jika IQ nya belum mencapai skor standar yang ditentukan.

Kecerdasan setiap orang tidak bisa diukur hanya dalam bentuk angka, maka menurut Howard Gardner setidaknya ada delapan macam kecerdasan yang dimiliki oleh manusia, yaitu kecerdasan linguistik (berkaitan dengan bahasa), kecerdasan logis-matematis (berkaitan dengan nalar logika dan matematika), kecerdasan spasial (berkaitan dengan ruang dan gambar), kecerdasan musikal (berkaitan dengan musik, irama, dan bunyi/suara), kecerdasan badani-kine stetik (berkaitan dengan badan dan gerak tubuh), kecerdasan interpersonal (berkaitan dengan hubungan antar pribadi, sosial), kecerdasan intrapersonal (berkaitan dengan hal-hal yang sangat mempribadi), dan kecerdasan naturalistik. Beberap kecerdasan tersebut lebih berkaitan dengan kapasitas/kemampuan untuk memecahkan masalah-masalah dan menciptakan produk-produk dan karya-karya. Kecerdasan tersebut tidak menonjol satu per-satu tetapi dapat menonjol secara bersamaan, artinya setiap individu tidak hanya terbatas pada satu jenis kecerdasan saja. Setiap peserta didik memiliki jenis multiple intelligences yang berbeda beda dalam membantu proses pembelajaran di sekolah (Kang et al., 2016; Şener \& Çokçalışkan, 2018; Sharpe \& Kelman, 2011).

Pada pembelajaran sains tidak hanya merupakan kumpulan pengetahuan saja, tetapi didalam sains terkandung hal lain. Pembelajaran sains mengandung empat hal yaitu, konten atau produk, proses atau metode, sikap dan teknologi. Sains sebagai konten atau produk berarti bahwa dalam sains terdapat fakta-fakta, prinsip-prinsip dan teori-teori yang telah dibuktikan kebenarannya. Sains sebagai proses atau metode berarti bahwa sains merupakan suatu proses untuk mendapatkan ilmu pengetahuan (Markaki, 2014; Perovic, 2014; Yacoubian, 2018). Pemahaman tersebut dapat menumbuhkan rasa akan pentingnya hakikat yang ada didalam pembelajaran biologi dimana pemahaman tersebut dapat diaplikasikan dengan keterampilan proses sains. Hal lain yang menjadi aspek pokok dalam pembelajaran sains adalah anak dapat menyadari keterbatasan pengetahuan mereka sehingga memicu anak untuk menggali berbagai pengetahuan yang baru, dan akhirnya dapat mengaplikasikannya dalam kehidupan mereka. Beberapa keterampilan proses dasar sains yang harus mereka lakukan berasal dari dasar 
pemahaman dan merupakan komponen dari proses yang lebih kompleks. Proses dasar adalah: 1) Mengamati. Menggunakan satu atau lebih dari lima indera untuk melihat karakteristik objek atau peristiwa; 2) Berkomunikasi. Menyampaikan informasi melalui bahasa, gambar, atau cara lain representasi. Menggunakan grafik juga dapat menjadi sarana komunikasi; 3) mengklasifikasi. Menempatkan sesuatu ke dalam kategori sesuai dengan karakteristik tertentu. Klasifikasi termasuk menciptakan dan menggunakan sistem klasifikasi baru serta menggunakan sistem orang lain; 4) mengukur. Membuat observasi kuantitatif dengan membandingkan hal satu sama lain atau satuan ukuran; 5) memprediksi, yakni meramalkan apa yang akan terjadi; 6) inferensi, yaitu meramalkan apa yang sudah diamati.

Oleh karena itu dalam mengembangkan keterampilan proses sains tersebut perlu memperhatikan kemampuan atau multiple intelligences (kecerdasan majemuk) siswa, terutama pada delapan kecerdasan majemuk yang diuraikan oleh Howard Gardner. Pada tahun 1983 Howard Gardner mengembangkan teorinya yang dikenal sebagai dengan multiple intelligences (Sindora, 2002). Teorinya tersebut berdasarkan pada pendapatnya "bahwa setiap manusia mengembangkan keterampilan penting untuk cara hidupnya". la mendefinisikan intelligences sebagai kemampuan untuk menyelesaikan masalah dan menciptakan produk yang berharga. Berdasarkan analisis tersebut ada 8 intelligences pada diri setiap individu yakni adalah; intelligences liguistik, intelligences logika - matematika, intelligences spasial, intelligences kinestetik- jasmani, intelligences musikal, intelligences naturalis, intelligences intrapersonal, dan intelligences interpersonal. Semakin tinggi tingkat kecerdasan siswa, akan semakin mudah baginya dalam memahami suatu konsep dan prinsip dibanding orang lain yang mempunyai tingkat kecerdasan lebih rendah.

Beberapa penjelasan tersebut mengindikasikan adanya hubungan multiple intelligences dengan keterampilan proses sains peserta didik. Kedua variabel tersebut penting untuk diperhatikan oleh pendidik, karena multiple intelligences merupakan bentuk kecerdasan yang harus dikembangkan oleh siswa dan dalam keterampilan proses dasar sains siswa diberikan kesempatan untuk memeriksa proses pembelajaran secara langsung dan berpikir tentang menerapkannya dalam konteks ilmiah.

Dari informasi yang didapatkan penulis, bahwa SMA Negeri 4 Cibinong sudah menggunakan kurikulum 2013 yang dimana menuntut siswa aktif dalam proses pembelajaran dikelas maupun diluar kelas. Menurut guru mata pelajaran Biologi sebagian keterampilan proses dasar sains dimunculkan pada proses pembelajaran untuk mengaktifkan siswa dikelas ataupun di luar kelas ketika melaksanakan praktikum. Pada sekolah SMA Negeri 4 Cibinong terdapat 1 Labotarorium Biologi yang dapat digunakan oleh siswa dalam kegiatan praktikum di sekolah, fasilitas Laboratorium Biologi ini menampung 1 kelas beserta laboran. Menurut guru biologi yang berada di sekolah, untuk penerapan keterampilan proses sains ke siswa pada proses pembelajaran cukup baik namun terkadang ada beberapa kendala yang dirasakan oleh guru ketika ingin menumbuhkan keterampilan proses sains dalam 
proses pembelajaran berlangsung salah satunya yakni secara bersamaan laboratorium digunakan oleh lebih dari satu kelas.

\section{METODE PENELITIAN}

Penelitian ini dilaksanakan di SMA Negeri 4 Cibinong, Jl. H. Moh. Ashari No.33, 16125, Kecamatan Cibinong, Kabupaten Bogor. Penelitian ini dilakukan pada yahun ajaran 2020/2021. Metode yang digunakan dalam penelitian ini kuantitatif dengan pendekatan korelasional.

Terdapat dua variabel pertama adalah variabel perlakuan $(X)$ yaitu multiple intelligences lalu variabel kedua dalam penelitian ini adalah variabel terikat $(\mathrm{Y})$ yaitu keterampilan proses sains siswa. Populasi yang digunakan dalam penelitian ini adalah seluruh siswa kelas XI MIPA SMA Negeri 4 Cibinong tahun ajaran 2020/2021. Penentuan sampel dilakukan dengan menggunakan teknik proportional random sampling, yaitu yaitu pengambilan sample secara acak. Berdasarkan teknik proportional random sampling, mendapatkan jumlah sampel 154 siswa/siswi. Perhitungan yang digunakan dengan rumus Slovin.

Sebelum penelitian dilaksanakan instrumen soal keterampilan proses sains dan instrumen kuisioner multiple intelligences di uji cobakan pada siswa. Uji coba ini dilakukan untuk mengetahui tingkat validitas dan reliabilities soal tersebut sehingga dapat digunakan sebagai alat pengumpulan data, setelah dilakukan uji coba, instrument soal keterampilan proses sains dan kuisioner multiple intelligences tersebut dikalibrasi. Dalam menganalisis data terlebih dahulu perlu dilakukan pengujian prasayart analisis yang terdiri dari melakukan uji normalitas dan uji homogenitas data.

Uji normalitas untuk mengetahui apakah masing - masing variabel dalam penelitian berdistribusi normal atau tidak. Pengujian ini menggunakan uji Kolmogorov Smirnov Test dengan SPSS versi 26. Jika nilai signifikan yang diperoleh $\alpha>(0,05)$, maka sampel berasal dari populasi berdistribusi normal. Sedangkan jika nilai signifikan yang diperoleh $\alpha<(0,05)$, maka sampel bukan berasal dari populasi berdistribusi normal, taraf signifikan $\alpha=0,05$. Uji homogenitas dilakukan untuk mengetahui apakah sampel atau populasi bersifat homogen atau tidak. Perhitungan dengan menggunakan Levene Test dengan SPSS versi 26 . Apabila nilai signifikan yang diperoleh $>\alpha(0,05)$, maka variansi setiap sampel sama (homogen). Sedangkan jika nilai signifikan yang diperoleh $<\alpha(0,05)$, maka variansi setiap sampel tidak sama (tidak homogen), taraf signifikan $\alpha=0,05$. Uji hipotesis diuji menggunakan metode statistik parametris berupa uji korelasi dan regresi dengan bantuan tabel output SPSS dalam menentukan adanya hubungan antara Multiple Intelligences $(\mathrm{X})$ dan Keterampilan Proses Sains $(\mathrm{Y})$. Untuk dapat memberi interpretasi terhadap kuatnya hubungan antara variabel $X$ dan $Y$ maka dapat digunakan pedoman seperti berikut:

\begin{tabular}{cc}
\multicolumn{2}{c}{ Tabel 1. Pedoman Interpretasi Koefisien Korelasi } \\
\hline Interval Korelasi & Hubungan Variabel \\
\hline $0,00-0,199$ & Sangat Rendah \\
$0,20-0,399$ & Rendah \\
$0,40-0,599$ & Cukup Tinggi \\
$0,60-0,799$ & Tinggi \\
$0,80-1,000$ & Sangat Tinggi \\
\hline
\end{tabular}


Dalam analisis korelasi regresi tersebut, hipotesis statistik yang akan diuji yaitu:

Ho: $\rho x y \leq 0$, tidak terdapat hubungan positif antara multiple ilntelligences dengan keterampilan proses sains.

Ha: $\rho x y>0$, terdapat hubungan positif antara multiple intelligences dengan keterampilan proses sains.

\section{HASIL PENELITIAN DAN PEMBAHASAN}

Penelitian ini membahas dua variabel yang terdiri dari satu variabel bebas dan variabel terikat. Variabel bebas yaitu multiple intelligences $(X)$ sedangkan variabel terikat yaitu keterampilan proses sains $(Y)$. Banyaknya sampel yang didapatkan sebanyak 154 responden yang terdiri dari siswa-siswi kelas XI SMA Negeri 4 Cibinong. Keterampilan Proses Sains

Variabel keterampilan proses sains menggunakan 36 soal pilihan ganda, dengan jumlah sampel 154 reponden, didapatkan data hasil skor tertinggi 36 dan skor terendah 11 dengan rentang skor 25 . Skor rata-rata (mean) 28,33, dengan nilai tengah (median) 29, sedangkan nilai yang sering muncul (modus) 29. Berdasarkan hasil perhitungan diperoleh nilai varian sebesar 23,05, dengan standar deviasi (SD) sebesar 4,80 . Skor total sebesar 4366 dengan jarak antar kelas 3 . Histogram distibusi frekuensi data keterampilan proses sains dapat dilihat pada Gambar 1.

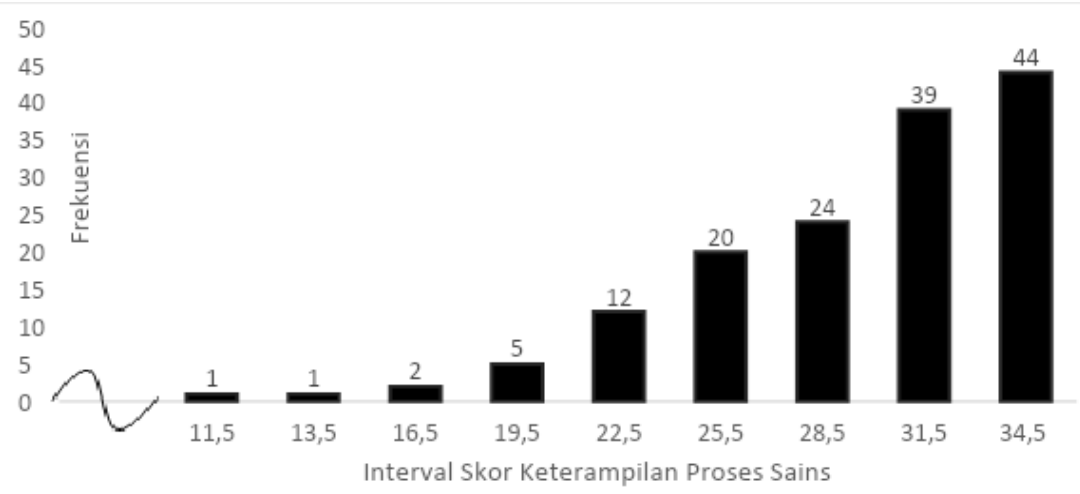

\section{Gambar 1. Histogram Distribusi Frekuensi Data Keterampilan Proses Sains Siswa}

Berdasarkan histogram di atas menunjukkan bahwa penyebaran skor Keterampilan proses sains berada pada rentang nilai 11 - 13 sebesar $1 \%$ sebanyak 1 responden, kemudian rentang 14 - 16 sebesar $1 \%$ sebanyak 2 responden, rentang 17 - 19 sebesar 3\% sebanyak 5 responden, rentang $20-22$ sebesar $8 \%$ sebanyak 12 responden, rentang $23-25$ sebesar $13 \%$ sebanyak 20 responden, rentang 26 28 sebesar $16 \%$ sebanyak 24 responden, rentang $29-31$ sebesar $25 \%$ sebanyak 39 responden dan rentang 35 - 37 sebesar $5 \%$ sebanyak 7 responden.

\section{Multiple Intelligences}

Berdasarkan jawaban responden didapatkan data hasil skor tertinggi tertinggi 128 dan skor terendah 71 dengan rentang skor 57 . Skor rata-rata (mean) 88,50, dengan nilai tengah (median) 87, sedangkan nilai yang sering muncul (modus) 86. Berdasarkan hasil perhitungan diperoleh nilai varian sebesar 83,53, dengan standar 
deviasi (SD) sebesar 9,14. Skor total sebesar 13629 dengan jarak antar kelas 6 . Histogram distibusi frekuensi data multiple intelligences dapat dilihat pada Gambar 2.

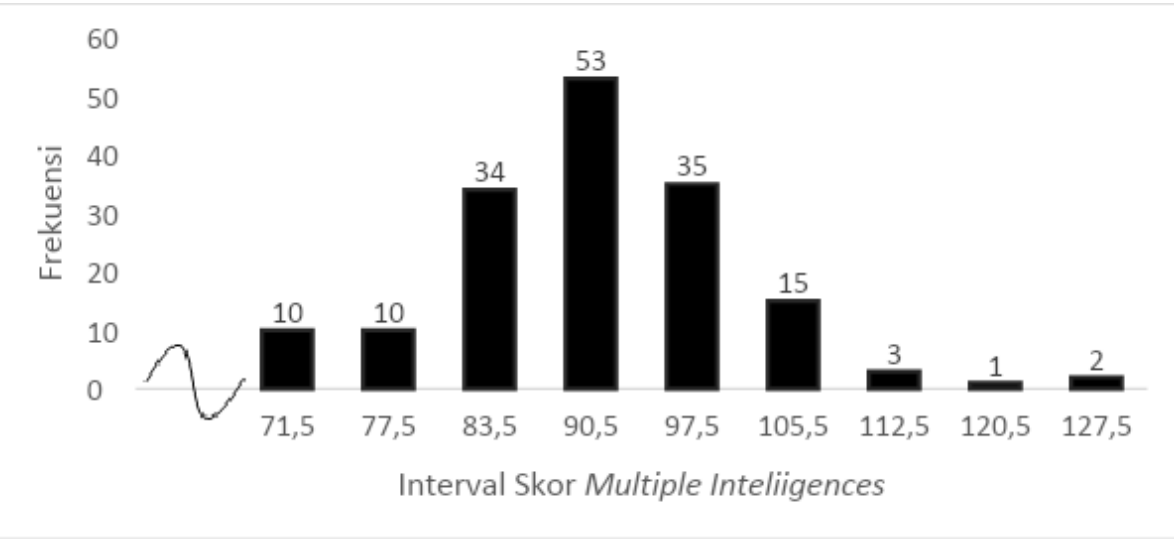

Gambar 2. Histogram Distibusi Frekuensi Data Multiple Intelligences

Berdasarkan histrogram di atas menunjukkan bahwa penyebaran skor multiple intelligences berada pada rentang 71 - 77 sebesar $6 \%$ sebanyak 10 responden, rentang 78 - 83 sebesar $22 \%$ sebanyak 34 responden, rentang $84-90$ sebesar $35 \%$ sebanyak 54 responden, rentang 91 - 97 sebesar 23\% sebanyak 35 responden, rentang 98 - 105 sebesar 10\% sebanyak 15 responden, rentang 106 - 112 sebesar $2 \%$ sebanyak 3 responden, , rentang $113-120$ sebesar $0 \%$ sebanyak 0 responden, rentang $121-127$ sebesar $1 \%$ sebanyak 1 responden, dan rentang $128-134$ sebesar $1 \%$ sebanyak 2 responden.

Analisis prasyarat data penelitian dilakukan dengan melakukan perhitungan uji normalitas dengan menggunakan uji Kolmogorov Smirnov Test dengan SPSS versi 26 dan uji homogenitas dengan menggunakan Levene Test dengan SPSS versi 26. Hasil uji normalitas disajikan pada Tabel 2.

Tabel 2. Hasil Uji Normalitas variabel $X$ dan $Y$

\begin{tabular}{llr}
\hline & \multicolumn{1}{c}{ Unstandardized Residual } \\
\hline $\mathrm{N}$ & & 154 \\
Normal & Mean & .0000000 \\
& Std. Deviation & \\
Most Extreme & Absolute & 4.79312099 \\
Differences & Positive & .120 \\
& Negative & .069 \\
& & -.120 \\
Test Statistic & & .120 \\
Asymp. Sig. (2-tailed) & & $.150^{c}$ \\
$\begin{array}{l}\text { a. Test distribution is Normal. } \\
\text { b. Calculated from data. } \\
\text { C. Lilliefors Significance Correction. }\end{array}$ \\
\hline
\end{tabular}


Berdasarkan hasil perhitungan di atas diperoleh nilai 0,150 >0,05, maka dapat disimpulkan bahwa uji normalitas galat baku taksiran antara keterampilan proses sains dengan multiple intelligences dari populasi yang berdistribusi normal.

Untuk menentukan homogenitas data kedua variabel tersebut, dilaukan pengujian homogenitas dengan menggunakan Levene Test dengan SPSS versi 26. Berdasarkan hasil perhitungan di atas diperoleh nilai signifikan adalah 0,682, maka $0,682>0,05$ disimpulkan bahwa varian data keterampilan proses sains dengan multiple intelligences dari populasi yang homogen. HAsil homogenitas disajikan pada Tabel 3.

Tabel 3. Hasil Uji Homogenitas variabel $X$ dan $Y$

\begin{tabular}{llcccc}
\hline & Levene Statistic & df1 & df2 & Sig. \\
\hline Variabel X & Based on Mean & 1.946 & 29 & 118 & .682 \\
dan $Y$ & $\begin{array}{l}\text { Based on Median } \\
\text { Based on Median and with }\end{array}$ & 1.118 & 29 & 118 & .329 \\
& $\begin{array}{l}\text { adjusted df } \\
\text { Based on trimmed mean }\end{array}$ & 1.118 & 29 & 73.90 & .342 \\
\cline { 2 - 6 } & & 1.869 & 29 & 118 & .104 \\
\hline
\end{tabular}

Pengujian hipotesis dilakukan setelah data hasil perhitungan yang dilakukan telah dinyatakan berdistribusi normal dan homogen. Hipotesis diuji menggunakan metode statistik parametris berupa uji korelasi dan regresi dengan bantuan tabel output SPSS dalam menentukan adanya hubungan antara Multiple Intelligences (X) dan Keterampilan Proses Sains (Y). Pengujian hipotesis dilakukan perhitungan penetapan persamaan regresi keterampilan proses sains dengan multiple intelligences menunjukan bahwa nilai konstanta (a) sebesar 27,228 dan nilai konstanta (b) sebesar $0,128 x$ sehingga persamaan regresi $\hat{Y}=27,228+0,128 x$.

Perhitungan lineriatas dilihat regresi pada nilai deviation from linierity menunjukan signifikansi 0,713 lebih besar dari 0,05 yang artinya penyimpangan dari keadaan linier adalah tidak signifikan, maka dapat disimpulkan bahwa kedua variabel tersebut dengan persamaan regresi $\hat{Y}=27,228+0,128 x$ adalah linier.

Berdasarkan dari persamaan regresi tersebut dapat diinterpretasikan bahwa sebelumnya multiple intelligences telah memiliki keterampilan proses sains secara konstanta sebesar 27,228 . Setiap kenaikan satu unit multiple intelligences aakan menyebabkan pertambahan keterampilan proses sains sebesar 0,128 unit. Secara grafik persamaan regresi tersebut ditampilkan pada Gambar 3.

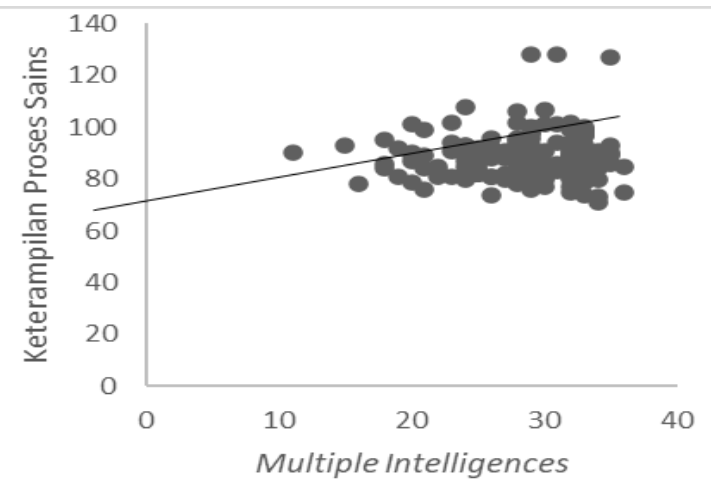

Gambar 3. Diagram Pencar Hubungan antara Keterampilan Proses Sains dengan Multiple Intelligences 
Pengujian menetapkan koefisien korelasi dan signifikannya menggunakan SPSS 26 yang dapat dilihat pada hasil pengujian korelasi antara variabel $X$ dan $Y$. Hasil uji menetapkan koefisien korelasi disajikan pada Tabel 4.

Tabel 4. Ringkasan Hasil Uji Korelasi

\begin{tabular}{rlrr}
\hline & & KPS & MI \\
\hline KPS & Pearson Correlation & 1 & .409 \\
& Sig. (2-tailed) & & .010 \\
& $\mathrm{~N}$ & 154 & 154 \\
$\mathrm{MI}$ & Pearson Correlation & .409 & 1 \\
& Sig. (2-tailed) & .037 & 154 \\
\hline & $\mathrm{N}$ & 154 & \\
\hline
\end{tabular}

Berdasarkan tabel output SPSS diatas menunjukan bahwa korelasi koefisien antara multiple intelligences dengan keterampilan proses sains ( $r y$ ) sebesar 0,409 $>0$ yang artinya terdapat hubungan positif antara multiple intelligences dengan keterampilan proses sains, dan nilai signifikansinya sebesar 0,037 kurang dari 0,05 sehingga dapat disimpulkan bahwa korelasi tersebut signifikan.

Disimpulkan bahwa $\mathrm{HO}$ ditolak dan Ha diterima yang artinya hipotesis penelitian yang menyatakan bahwa tidak terdapat hubungan multiple intelligences dengan keterampilan proses sains ditolak dan hipotesis yang menyatakan bahwa terdapat hubungan positif antara multiple intelligences dengan keterampilan proses sains diterima. Dengan demikian hasil penelitian menyimpulkan bahwa terdapat hubungan positif antara multiple intelligences dengan keterampilan proses sains. Sesuai dengan hasil penelitian Hal ini seperti pendapat Samsudin, dkk (2015) mengatakan kecerdasan majemuk terkait dengan pengajaran sains yang disukai berorientasi eksperimental dan keterampilan proses sains. Dengan ini kecerdasan majemuk dapat diterapkan dalam pendidikan untuk memenuhi kebutuhan siswa dalam proses pembelajaran.

Hasil analisis dan pengujian hipotesis, diperoleh temuan bahwa terdapat hubungan positif multiple intelligences dengan keterampilan proses sains. Berarti asumsi - asumsi yang mendasari pengkajian teoritis didukung oleh data yang diperoleh dari responden. Hubungan antara multiple intelligences dengan keterampilan proses sains berdasarkan penelitian ini ditunjukan dari analisis statistik yang menghasilkan koefisien korelasi (r) sebesar 0,409 sedangkan koefisien determinasi (r2) sebesar 0,167 . Dapat di artikan kenaikan atau penurunan keterampilan proses sains dapat ditentukan oleh variabel multiple intelligences sebesar 16,7\%. Derajat kekuatan hubungan yang ditunjukkan oleh hasil persamaan regresi $\hat{Y}=27,228+0,128 x$, dapat diinterprestasikan bahwa siswa yang memiliki multiple intelligences telah memiliki keterampilan proses sains sebesar 27,228. Setiap kenaikan satu unit nilai multiple intelligences menyebabkan pertambahan keterampilan proses sains sebesar $0,128 x$ unit, sehingga multiple intelligences $(\mathrm{X})$ dapat meningkatkan atau mengembangkan keterampilan proses sains siswa $(\mathrm{Y})$. Hal ini menggambarkan bahwa keterampilan proses sains pada siswa dapat ditentukan oleh multiple intelligences yang dimiliki siswa. 
Berdasarkan hasil penelitian yang dilakukan menunjukan bahwa terdapat hubungan antara multiple intelligences dengan keterampilan proses sains siswa yang ditandai dengan nilai koefisien korelasi ( $r$ ) sebesar 0,409 dimana multiple intelligences suatu kecerdasan individu yang berkaitan dengan kapasitas atau kemampuan untuk memecahkan masalah. Setiap siswa atau individu memiliki multiple intelligences namun hanya ada beberapa yang dominan atau menonjol pada diri masing - masing individu siswa yang dapat mempengaruhi keterampilan proses sains mereka di sekolah. Sehingga setiap masing - masing siswa dapat meyelesaikan sebuah masalah dengan kecerdasannya masing - masing, asumsinya adalah semua orang memiliki kecerdasan ini tetapi pada setiap orang salah satunya lebih menonjol. Cara pandang multiple intelligences bahwa semua anak atau siswa memberikan ruang gerak yang luas bagi siswa. Perilaku dan kecenderungan siswa diamati dan diidentifikasi. Setiap siswa memiliki kecerdasan majemuk pada tingkatan yang berbeda. Perbedaan ini akan berdampak pada pembelajaran siswa. Setiap siswa akan memiliki kemampuan kognitif, afektif yang berbeda dan hasil belajar psikomotorik (Ichsan \& Mulyani, 2018; Nabilah et al., 2019; Nam, 2017). Pada multiple intelligences ini kemampuan pada diri individu atau siswa yang dapat menumbuhkan dan mengembangkan kemampuan kognitif secara lebih adil. Menurut Riyanti, dkk (2020) Salah satu faktor yang muncul dari dalam diri seseorang adalah intelijen. Intelijen merupakan salah satu internal yang penting faktor dalam proses pembelajaran siswa, karena kecerdasan menentukan kualitas belajar siswa yang mana secara langsung atau secara tidak langsung mempengaruhi proses belajar siswa.

Hubungan antara multiple intelligences dengan keterampilan proses sains siswa dapat dilihat pada kecerdasan logis - matematis berkaitan dengan nalar logika kecerdasan ini dibutuhkan dalam memahami konsep dan prinsip yang ada. Pada keterampilan proses sains kecerdasan logis - matematis dapat membantu proses menyusun hipotesis keterampilan proses sains dimana siswa dapat menentukan hipotesis yang muncul dari nalar digabungkan dengan konsep yang sudah dipahami siswa. Penerapannya dalam proses pembelajaran pada penggunaan media pembelajaran yang melibatkan siswa dan melakukan praktikum. Lalu pada kecerdasan intrapersonal dapat dikaitkan pada ketertarikannya dalam menyelesaikan suatu masalah, dan memiliki tujuan sebelum melakukan suatu pekerjaan. Pada kecerdasan naturalis siswa memiliki kemampuan untuk mengenali dan mengklasifikasi aneka spesies, flora dan fauna. Pengaplikasian dalam proses pembelajaran misalnya melakukan proses pembelajaran di luar ruang kelas, baik dalam lingkungan sekolah maupun di luar lingkungan sekolah. Pada kecerdasan interpersonal berpengaruh terhadap pembelajaran sains, karena pada kecerdasan ini siswa mengetahui dengan baik kekuatan dan kelemahan dirinya dengan berinteraksi teman sebaya dan senang bekerja dalam kelompok termasuk pengembangan keterampilan proses sains dalam proses berkomunikasi (Imamura, 2017; Motallebzadeh et al., 2018; Razzaq et al., 2018; Sawicki \& Wegener, 2018). Pengaplikasian dalam proses pembelajaran yakni dengan membagi siswa baik dalam kelompok besar maupun kelompok kecil. 
Pada kecerdasaan kinestatik dapat membantu proses melaksanakan percobaan atau penyelidikan pada keterampilan proses sains. Salah satu pengaplikasiannya dalam proses pembelajaran yaitu dalam kegiatan praktikum dan penggunaan media pembelajaran yang melibatkan siswa dalam penggunaannya. Keterkaitan ini dilihat berdasarkan tahapan-tahapan keterampilan proses yang merupakan bentuk pengembangan multiple intelligences siswa. Keterampilan proses sains dalam proses mengamati mengandung kecerdasan naturalistik, menyusun hipotesis mengandung pengembangan kecerdasan logis-matematika, mengomunikasikan mengandung beberapa kecerdasan, seperti intrapersonal, interpersonal, dan visual - spasial. Setiap manusia memiliki banyak kecerdasan, kecerdasan manusia dapat dilihat dari multi dimensi. Multiple intelligences pada siswa dapat terlihat pada perilaku seharihari, salah satunya dapat diketahui dalam proses pembelajaran di sekolah (Samsudin et al., 2015; Sharpe \& Kelman, 2011; Trahan et al., 2019; Tsalas et al., 2017). Pada proses pembelajaran dikelas, salah satu contohnya siswa yang memiliki kecerdasan naturalistik yang menonjol belum tentu keterampilan proses sains di kelas baik, karena untuk memiliki keterampilan proses sais yang baik, juga membutuhkan kecerdasan yang lainnya.

Multiple intelligences sebagai kemampuan memecahkan persoalan dan menghasilkan produk baru dalam suatu latar yang bermacam-macam dan dalam situasi yang nyata (Gardner, 2013). Sedangkan dapat dilihat multiple intelligences dapat mempengaruhi keterampilan proses sains, hal ini dikarenakan dengan meningkatnya multiple intelligences tersebut juga meningkat keterampilan proses sains. Setiap siswa atau individu memiliki multiple intelligences namun hanya ada beberapa yang dominan atau menonjol pada diri masing - masing yang dapat mempengaruhi keterampilan proses sains mereka di sekolah. Sehingga setiap masing - masing siswa dapat meyelesaikan sebuah masalah dengan kecerdasan nya masing - masing. Dengan demikian, mengembangkan multiple intelligences yang sudah ada sangat penting guna mengembangkan keterampilan proses sains. Lalu siswa di sekolah mengalami proses perkembangan kognitif, sikap dan psikomotor dengan pesat. Pengembangan multiple intelligences dapat dilakukan dalam kegiatan pembelajaran, salah satunya melalui pembelajaran sains. Pembelajaran IPA atau sains bertujuan agar siswa memiliki keterampilan proses sains (Berland et al., 2016; Calado et al., 2018; Chen et al., 2015; Cirillo, 2014; Demir, 2015; Saputro et al., 2019; Udompong et al., 2014). Dalam pengembangan keterampilan proses sains ini, siswa secara tidak langsung dilatih untuk mengembangkan multiple intelligences. Hal ini seperti pendapat Samsudin, dkk (2015) mengatakan kecerdasan majemuk terkait dengan pengajaran sains yang disukai berorientasi eksperimental dan keterampilan proses sains. Dengan ini kecerdasan majemuk dapat diterapkan dalam pendidikan untuk memenuhi kebutuhan siswa dalam proses pembelajaran.

Selain pada model pembelajaran salah satu faktor yang lainnya yaitu memberikan soal berbentuk HOTS (Higher Order Thinking Skills) dimana dapat menstimulus atau meningkatkan proses berpikir siswa dalam level kognitif yang dikembangkan dari berbagai konsep setelah itu keterampilan proses sains siswa pun 
secara tidak langsung akan berkembang dengan baik. HOTS adalah bagaimana meningkatkan kemampuan berpikir peserta didik pada level yang lebih tinggi, terutama yang berkaitan dengan kemampuan untuk berpikir secara kritis dalam menerima berbagai jenis informasi, berpikir kreatif dalam memecahkan suatu masalah menggunakan pengetahuan yang dimiliki serta membuat keputusan dalam situasisituasi yang kompleks (Aisyah et al., 2018; Garcia, 2015; Ichsan et al., 2018, 2019, 2020; Istiyono et al., 2020; Purwanto et al., 2020; Rahmayanti et al., 2020). Dengan pernyataan sebelumnya menunjukan soal hots dapat mengembangkan keterampilan proses sains siswa di sekolah terjadi ketika siswa mengaitkan informasi baru dengan infromasi yang sudah tersimpan di dalam ingatannya dan mengaitkannya serta mengembangkan informasi tersebut untuk mencapai suatu tujuan atau menemukan suatu penyelesaian dari suatu keadaan yang sulit dipecahkan.

\section{SIMPULAN DAN SARAN}

Berdasarkan hasil penelitian yang didukung oleh data yang diperoleh di lapangan, hasil pengujian hipotesis dan pembahasan hasil penelitian, maka dapat ditarik kesimpulan bahwa terdapat hubungan positif antara multiple intelligences dengan keterampilan proses sains siswa kelas XI MIPA 1 - 7 di SMA Negeri 4 Cibinong. Kekuatan hubungan antara multiple intelligences dengan keterampilan proses sains siswa dapat dilihat dari angka korelasi ( $r$ ) sebesar 0,409 sedangkan koefisien determinasi $(r 2)$ sebesar 0,167 dengan persamaan $\hat{Y}=27,228+0,128 x$.

\section{UCAPAN TERIMA KASIH}

Terimakasih diucapkan kepada seluruh pihak yang sudah membantu dalam kelancaran penelitian ini.

\section{RUJUKAN}

Aisyah, A., Salehuddin, K., Aman, I., Yasin, R. ., \& Mimiko, N. (2018). Eliciting elements of higher order thinking skills in the higher secondary examination question structure in japan and malaysia aznur. Proceedings of the Regional Conference on Science, Technology and Social Sciences (RCSTSS 2016), Rcstss 2016, 455464. https://doi.org/10.1007/978-981-13-0074-5

Berland, L. K., Schwarz, C. V., Krist, C., Kenyon, L., Lo, A. S., \& Reiser, B. J. (2016). Epistemologies in practice: Making scientific practices meaningful for students. Journal of Research in Science Teaching, 53(7), 1082-1112. https://doi.org/10.1002/tea.21257

Calado, F. M., Scharfenberg, F. J., \& Bogner, F. X. (2018). Science-technologysociety-environment issues in German and Portuguese biology textbooks: influenced of the socio-cultural context? International Journal of Science Education, Part B: Communication and Public Engagement, 8(3), 266-286. https://doi.org/10.1080/21548455.2018.1486051

Camacho, D. J., \& Legare, J. M. (2015). Opportunities to create active learning techniques in the classroom. Journal of Instructional Research, 4, 38-45.

Chen, S. J., Chou, Y. C., Yen, H. Y., \& Chao, Y. L. (2015). Investigating and structural modeling energy literacy of high school students in Taiwan. Energy Efficiency, 8(4), 791-808. https://doi.org/10.1007/s12053-015-9327-5 
Cirillo, M. C. (2014). Science and environmental stewardship. Global Bioethics, 25(2), 114-124. https://doi.org/10.1080/11287462.2014.922317

Cukurova, M., \& Bennett, J. (2018). Students' knowledge acquisition and ability to apply knowledge into different science contexts in two different independent learning settings. Research in Science and Technological Education, 36(1), 1734. https://doi.org/10.1080/02635143.2017.1336709

Demir, M. (2015). Third grade elementary students??? perception of science. International Electronic Journal of Elementary Education, 7(2), 157-168.

Garcia, L. C. (2015). Environmental science issues for higher-order thinking skills (hots) development: A case study in the Philippines. In Biology Education and Research in a Changing Planet (pp. 45-54). https://doi.org/10.1007/978-981-287524-2

Gardner, H. (2013). Multiple Inteligences; Kecerdasan Majemuk Teori Praktik Ter. Alexander Sindoro. Interaksara.

Ichsan, I. Z., Iriani, E., \& Hermawati, F. M. (2018). Peningkatkan Keterampilan Berpikir Tingkat Tinggi (Higher Order Thinking Skills) Pada Siswa Sekolah Dasar Melalui Video Berbasis Kasus Pencemaran Lingkungan. Edubiotik: Jurnal Pendidikan, Biologi Dan Terapan, 3(02), 12-18.

Ichsan, I. Z., \& Mulyani, S. W. W. (2018). Improving Students' Motoric Skills Through Demonstration Method in Recycling Plastic Waste. JPBI (Jurnal Pendidikan Biologi Indonesia), 4(2), 189-194. https://doi.org/10.22219/jpbi.v4i2.5890

Ichsan, I. Z., Rahmayanti, H., Purwanto, A., Sigit, D. V., Irwandani, I., Ali, A., Susilo, S., Kurniawan, E., \& Rahman, M. M. (2020). COVID-19 outbreak on environment: Profile of islamic university students in HOTS-AEP-COVID-19 and PEB-COVID19. Tadris: Jurnal Keguruan Dan IImu Tarbiyah, 5(1), 167-178. https://doi.org/10.24042/tadris.v5i1.6283

Ichsan, I. Z., Sigit, D. V., Miarsyah, M., Ali, A., Arif, W. P., \& Prayitno, T. A. (2019). HOTS-AEP: Higher order thinking skills from elementary to master students in environmental learning. European Journal of Educational Research, 8(4), 935942. https://doi.org/10.12973/eu-jer.8.4.935

Imamura, M. (2017). Beyond the limitations of environmental education in Japan. Educational Studies in Japan: International Yearbook, 11, 3-14. https://doi.org/10.7571/esjkyoiku.11.3

Istiyono, E., Dwandaru, W. S. B., Setiawan, R., \& Megawati, I. (2020). Developing of computerized adaptive testing to measure physics higher order thinking skills of senior high school students and its feasibility of use. European Journal of Educational Research, 9(1), 91-101. https://doi.org/10.12973/eu-jer.9.1.91

Kang, H., Windschitl, M., Stroupe, D., \& Thompson, J. (2016). Designing, launching, and implementing high quality learning opportunities for students that advance scientific thinking. Journal of Research in Science Teaching, 53(9), 1316-1340. https://doi.org/10.1002/tea.21329

Markaki, V. (2014). Environmental Education through Inquiry and Technology. Science Education International, 25(1), 86-92.

Motallebzadeh, K., Ahmadi, F., \& Hosseinnia, M. (2018). Relationship between 21st century skills, speaking and writing skills: A structural equation modelling approach. International Journal of Instruction, 11(3), 265-276. https://doi.org/10.12973/iji.2018.11319a

Nabilah, S., Anwar, Y., \& Riyanto, R. (2019). Motoric mechanism with problem-based learning: Impact on students' higher-order thinking skills. Biosfer: Jurnal Pendidikan Biologi, 12(2), 182-193. 
https://doi.org/10.21009/biosferjpb.v12n2.182-193

Nam, C. W. (2017). The effects of digital storytelling on student achievement, social presence, and attitude in online collaborative learning environments. Interactive Learning Environments, 25(3), 412-427. https://doi.org/10.1080/10494820.2015.1135173

Perovic, S. (2014). Collaborative Research and Urban Educational Discourse in Contemporary Higher Education. Procedia - Social and Behavioral Sciences, 116, 4559-4563. https://doi.org/10.1016/j.sbspro.2014.01.985

Purwanto, A., Ichsan, I. Z., Nurfadhilah, N., Kurniawan, E., Ali, A., \& Singh, C. K. S. (2020). ESBOR: Analysis Students HOTS for Develop Digital Technology in Environmental Learning. International Journal of Advanced Science and Technology, 29(4), 3896-3904. http://sersc.org/journals/index.php/IJAST/article/view/24556

Rahmayanti, H., Ichsan, I. Z., Azwar, S. A., Purwandari, D. A., Pertiwi, N., Singh, C. K. S., \& Gomes, P. W. P. (2020). DIFMOL: Indonesian students' Hots and environmental education model during COVID-19. Journal of Sustainability Science and Management, 15(7).

Razzaq, A., Ansari, N. Y., Razzaq, Z., \& Awan, H. M. (2018). The Impact of Fashion Involvement and Pro-Environmental Attitude on Sustainable Clothing Consumption: The Moderating Role of Islamic Religiosity. SAGE Open, 8(2), 117. https://doi.org/10.1177/2158244018774611

Riyanti, Manurung, B., \& Sudibyo, M. (2020). The Contribution of Multiple Intelligences Aspects on Science Process Skills of High School Students in Ecology Topic. 384(Aisteel), 13-17. https://doi.org/10.2991/aisteel-19.2019.4

Samsudin, M. A., Haniza, N. H., Abdul-Talib, C., \& Mhd Ibrahim, H. M. (2015). The Relationship between Multiple Intelligences with Preferred Science Teaching and Science Process Skills. Journal of Education and Learning (EduLearn), 9(1), 53. https://doi.org/10.11591/edulearn.v9i1.1118

Saputri, A. C., Sajidan, S., Rinanto, Y., Afandi, A., \& Prasetyanti, N. M. (2019). Improving students' critical thinking skills in cell-metabolism learning using stimulating higher order thinking skills model. International Journal of Instruction, 12(1), 327-342. https://doi.org/10.29333/iji.2019.12122a

Saputro, A. D., Irwanto, Sri Atun, \& Wilujeng, I. (2019). The impact of problem solving instruction on academic achievement and science process skills among prospective elementary teachers. Elementary Education Online, 18(2), 496-507. https://doi.org/10.17051/ilkonline.2019.561896

Sawicki, V., \& Wegener, D. T. (2018). Metacognitive Reflection as a Moderator of Attitude Strength Versus Attitude Bolstering: Implications for Attitude Similarity and Attraction. Personality and Social Psychology Bulletin, 44(5), 1-15. https://doi.org/10.1177/0146167217744196

Şener, S., \& Çokçalışkan, A. (2018). An Investigation between Multiple Intelligences and Learning Styles. Journal of Education and Training Studies, 6(2), 125. https://doi.org/10.11114/jets.v6i2.2643

Sharif, A., \& Cho, S. (2015). 21st-century instructional designers: Bridging the perceptual gaps between identity, practice, impact and professional development. RUSC. Universities and Knowledge Society Journal, 12(3), 72-85. https://doi.org/10.7238/rusc.v12i3.2176

Sharpe, J., \& Kelman, I. (2011). Improving the disaster-related component of secondary school geography education in England. International Research in Geographical and Environmental Education, 20(4), 327-343. 
https://doi.org/10.1080/10382046.2011.619810

Sindora. (2002). Multiple Intelligences: Kecerdasan majemuk dalam praktik. Interaksara.

Trahan, M. H., Smith, K. S., \& Talbot, T. B. (2019). Past, Present, and Future: Editorial on Virtual Reality Applications to Human Services. Journal of Technology in Human Services, 37(1), 1-12. https://doi.org/10.1080/15228835.2019.1587334

Tsalas, N., Sodian, B., \& Paulus, M. (2017). Correlates of metacognitive control in 10year old children and adults. Metacognition and Learning, 12(3), 297-314. https://doi.org/10.1007/s11409-016-9168-4

Udompong, L., Traiwichitkhun, D., \& Wongwanich, S. (2014). Causal Model of Research Competency Via Scientific Literacy of Teacher and Student. Procedia Social and Behavioral Sciences, 116(2001), 1581-1586. https://doi.org/10.1016/j.sbspro.2014.01.438

Yacoubian, H. A. (2018). Scientific literacy for democratic decision-making. International Journal of Science Education, 40(3), 308-327. https://doi.org/10.1080/09500693.2017.1420266 